\title{
THE DOMINANCE OF POWER OVER THE FIGURE OF DONALD TRUMP IN THE OFFICIAL PRESIDENTIAL SPEECH OF THE UNITED STATES OF AMERICA (THE UNITED STATES RECOGNIZES JERUSALEM AS THE CAPITAL OF ISRAEL): A DISCOURSE ANALYSIS
}

\author{
Ayu Tiara Maretha \\ Postgraduate Program Faculty of Social and Political Science, University of Indonesia \\ marethaya19@gmail.com
}

\begin{abstract}
The act to boost nation building is not separated from the role of a political actor who represents a country. Donald Trump's decision to finally recognize Jerusalem as the capital of Israel is very contrary to US foreign policy over the past 7 decades, which makes it controversial. This raises questions about the dominance of power over a figure of the President of United States in representing his role as a political actor. This research aims to analyze the dominance of power over a figure of Donald Trump as The President of United States through his official presidential speech on recognizing Jerusalem as the capital of Israel. Using a discourse analysis by Teun A. Van Dijk, this research is done by analyzing structures of language based on the full transcript of the video, as The basic assumption of the study of critical discourse is that the language used for various functions has various consequences, whether it is governing, influencing, deciphering, filing, manipulating moving groups or persuading. It can also be implied that certain statement of a powerful political leader can be used to support nation building, in this case is the United States as a superpower.
\end{abstract}

Keywords: domination, power, Trump, nation building, United States, discourse, Van Dijk 


\section{INTRODUCTION}

Critical discourse analysis is a perspective, a position or attitude taken in a discourse study discipline that involves various disciplines: discourse analysis, psychology, history, social sciences, or linguistics. Therefore, various scientific disciplines are needed to help analyze, make descriptions and provide a theoretical framework that plays a role in criticizing justice or discrimination on the basis of gender, ethnicity, class, religion, or language. The basic assumption of the study of critical discourse is that the language used for various functions has various consequences, whether it is governing, influencing, deciphering, filing, manipulating moving groups or persuading (Haryatmoko, 2016: 77).

Language is used for a variety of functions and has various consequences. Language can be constructed so that the same phenomenon can be described in various ways. One of the most common is the news text that reports an event. On December 6, 2018, The New York Times published an article entitled Trump Recognizes Jerusalem as Israel's Capital and Orders U.S. Embassy to Move on its official page followed by a video and complete transcript of the official speech.

The President of the United States, Donald Trump, was controversial by formally issuing a statement that he recognized Jerusalem as the capital of Israel and stated that he would move the United States Embassy from Tel Aviv to Jerusalem. Quoted from Landler (2017), contrary to the foreign policy of the United States for more than 7 decades, what Trump has done is controversial. As the United States and other countries agreed not to recognize Israel since its formation in 1948, Trump said that the policy would never bring good results in resolving the Jerusalem and Palestinian disputes. In other words, this effort is considered a new approach to the handling of the Israeli-Palestinian conflict. Trying to recall the promises of his campaign, Trump said that the recognition of Jerusalem as the capital of Israel was a promise that the United States government had failed to realize before.

As the President of the United States, Trump's actions are inseparable from the dominance of the power of a political actor who wants to position certain powers. His jargon when campaigning is, "Make America Great Again" seems to be able to move the United States voters who want to restore their status as a superpower. But investigating Donald Trump personally as a political leader and actor, Jack Sackman in the Washington Post said that in addition to being less open to input, Trump was said to be more suitable to be an entrepreneur because of the lack of knowledge of foreign policy and diplomacy. Besides, some of Trump's statements before becoming President were also considered not substantive, one of which was the planned construction of a wall along the border with Mexico (Gustari, 2017). 
In this article, I used one theory of discourse analysis, namely critical discourse study by Teun A. Van Dijk which stated that language is a powerful mechanism of social control. As an object of research, I used an original video recordings and complete transcripts of Donald Trump's presidential speech posted on the online news page of The New York Times.

\section{Research Question}

Trump's framing as a political actor from a superpower is reflected in the Article II of Constitution which describes the power of a President of the United States which consists of 4 sections. The first part of Article II of this constitution outlines the scope of the president's power, such as (1) the executive body headed by the President and Vice President, (2) the method of election, and (3) the requirements for being able to hold positions. While the second part contains the authority over administrative power in appointing someone to fill high positions in government. The President is also given the authority to elect high-ranking officials and international agreements (with the approval of the senate), issue regulations and instructions as executive orders (having the power of law binding on federal agencies without the need for congressional approval), even the power to veto the RRU endorsed by congress. Based on the background above, Trump is known to have a dominant role in his power as a political actor in a superpower. Therefore, the following research questions were formulated: How would the dominance of power be the figure of Donald Trump based on a video speech about his official statement of the status of Jerusalem as the capital of Israel?

\section{Objectives}

With the dominant role in the United States as a superpower, it is interesting to understand the domination of power by Donald Trump and his representation of power through text. Using videos and transcripts of official speeches quoted from The New York Times news page, this study aims to understand the representation of the power of Trump's figure through a video of his official speech about Donald Trump's statement that acknowledges Jerusalem as the capital of Israel. It also provides an understanding that there is a concept of representation and domination in an official statement of a head of state regarding the issue he presents as a political actor.

\section{LITERATURE REVIEW}

The first literature reviewed is the article entitled Discourse Analysis News of the POLRI VS KPK Conflict in Kaltim Post (January 2015 Edition) by Dei Sanasta Queen. This study uses the theory of discourse analysis with a model developed by Teun A, Van Dijk to find out what is the content of a news text, elements that form news texts, sentences, paragraphs, and propositions. It is said that according to Van Djik, research on discourse is not enough based solely on text analysis, because the text is only the result of a 
production practice that must be observed. Here must also be seen how a text is produced, so we get a knowledge of why the text can be displayed the way it is.

I then used the article entitled WACANA ANALYSIS: Introduction to Media Text Analysis by Eriyanto (2001) to obtain a discourse analysis model specifically developed by Teun A. Van Dijk. In the discourse text analysis by Van Dijk, there is a text structure, namely (1) Macro Structure; global meaning of a text that can be observed from the topic or theme raised by a text, (2) Superstructure; the framework of a text such as the introduction, contents, concluding, and conclusions, and (3) Micro Structure; local meaning of a text that can be observed from the choice of words, sentences, and styles used by a text. One of the important elements of discourse revealed is Schematic, especially Self Schema which relates to how self is seen, understood, and described by someone. I use elements of this discourse to find out the representation of the power of Trump's figure through his official speech video.

The third literature is the article entitled Discourse Analysis Teun A Van Dijk in the Preaching of Gatra Magazine's Main Report on the Boycott of Israel from New York by Fauziah Mursid. Raising the issue of Israel and Palestine, I use Van Dijk's discourse analysis as a knife of analysis for this article. The news that was chosen did not only contain statements about the cases that occurred, but also there were additional meanings that supported the boycott action in question. It is said that the selection of words in the text and the news compositional scheme which is the reason for the form of inequality in the text.

In examining research on political actors and domination of power, I use a study entitled The Relationship of Political Actors in Power in Bangkalan (Study of Analysis of the Preparation of Regional Regulation Number 1 of 2015 concerning Guidelines for Election of Village Heads) by Syahrondy (2016). In line with the research objectives, this thesis aims to find out the power relations and actors that dominate in the process of drafting the Regional Regulation of election in Bangkalan regency. Through this research, it was found that actors with the most dominant power were executive actors.

In addition to previous research, I also obtained information about critical discourse analysis through the writings of Dr. Haryatmoko entitled Critical Discourse Analysis: The Foundation of Theory, Methodology, and Implementation (2016). This book provides an understanding of the characteristics and case studies of each discourse analysis method of many figures, including Fairclough, Ruth Wodak, and Teun A. Van Dijk. Through this paper, I obtain detailed information about various CDAs as a knife for various case analyzes.

\section{Substantive Theory: Domination of Power}

This theory is based on the assumption that in every society, there are two classes of population, namely those who control and are controlled. Classes that dominate generally 
have fewer numbers, carry out all political functions, monopolize power, and benefit from control over that power. Departing from Marx's definition of class, the ruler is the dominant group that runs political function so that it reminds us of the function of the state as a political expression of the dominant class and repressive weapons of the bourgeoisie. Social class will excel by dominating, or coercive through intellectual and moral leadership which is called hegemony.

Hegemony is a concept of reality that spreads through society in an institution and individual manifestations, which then shapes morality, customs, religion, political principles, and all social relations, especially in terms of intellectual and moral. Efforts to lead individuals to assess and view social problems within a predetermined framework, a chain of victory obtained through a consensus mechanism with existing institutional mechanisms in the community. Gramsci (Patria and Arief, 2003) considers hegemony not only intellectual and moral leadership without the practice of domination or coercion, in this case carried out by political actors.

According to Partant and Al-Barry (1994), domination is defined as mastery, good and strong position placement; great influence. In connection with power, Tawney (Soekanto, 1984) said that power is defined as the ability of individuals or groups of individuals to limit the desires of other groups, and prevent their desires from being controlled by other groups. In everyday life, the form of power appears in influence, charisma, leadership or authority. Power is the most common term and is often translated as power or strength. And in the context of this discussion, power is translated as power because of its connection with the social and political world.

\section{Discourse Theory: Critical Discourse Analysis by Teun A. Van Dijk}

Critical Discourse Analysis (CDA) has become a general label for a specific approach to the study of texts and words, developing from linguistic critical, semiotic critical and ways to investigate language, discourse and communication. Instead of the term Critical Discourse Analysis, Teun A. Van Dijk chose the term Critical Discourse Studies because this study not only involved critical analysis, but also critical theory and its critical applications (Haryatmoko, 2016: 77). The basic assumption of the study of critical discourse is that the language used for a variety of functions has various consequences, whether it is governing, influencing, describing, disdaining, manipulating moving groups or persuading.

In a book entitled Discourse as Structure and Process (1997), Van Dijk put forward the basic principles in conducting discourse analysis, one of which is the most important is the text and the conversation really takes place. As real data, the object of research is real data in the form of recordings or videos of conversations, or real texts used by mass media or education. According to Van Dijk, the data should not be edited, but examined as it is or as close as possible to the appearance in accordance with the original context. 
Because CDA is a critical analysis of the use of language, language according to Van Dijk, it is constructed and cbonstructed. Language is constructed to produce meaning through adjustments to the demands of its grammatical rules: use of vocabulary, terms or metaphors have led to certain meanings; grammar governs the use of verbs, themes, modalities; cohesion or integration of sentences; and the structure of the text reflects the logic of the argument for justification.

Language is said to construct when individuals try to give meaning to phenomena or engage in social activities, namely when language is used as a power strategy; and when stories or concepts can create reality. Therefore the discussion is not a neutral phenomenon, but is always related to the development of awareness of a problem.

According to Eriyanto in Discourse Analysis (2011), Van Dijk saw how social structure, domination, and power groups exist in society and how cognition and consciousness form and influence certain texts. The text according to van Dijk consists of several mutually supporting structures or levels. First, the macro structure is the general meaning of a text. Second, the superstructure is the framework of a text, such as the introduction, contents, conclusions and conclusions. Third, the meaning of a text that can be observed from the choice of words, sentences, and styles used in a text.

\section{Domination}

Domination is defined as mastery, good and strong position placement; great influence. With regard to power, power is the most common term describing power or power because of its relationship to the social and political world (Partant \& Al-Barry, 1994). Meanwhile domination in the political context can be found, at various levels, in many social relations of all societies, past and present. Political domination is understood as a condition experienced by people or groups when they depend on social relations in which several other people or groups use arbitrary power over them; and, furthermore, that it must be considered as an injustice to suffer under these conditions and therefore, as a matter of justice, political domination must be minimized in any society.

Trump's domination as a leader of a superpower made his domestic and foreign policies in the spotlight, especially regarding Trump's work programs that have influenced the countries of the world, is a manifestation of his dominant role as president of the United States. Trump's policies are protonistically with anti-free trade and high import duties on products made by developing countries that seem to protect the economy of their own countries so as to prevent other countries' industries from entering the country (Kotimah, 2016).

\section{Power}

Power is interpreted as the ability of a person or group to realize their own desires in communal action even if there is resistance from others who participate in the action. In social relations, strength means a person's ability to carry personality (even if opposed 
to resistance). The definition of power by Max Weber is limited to human social relations, especially in bringing the interests of a person or group of people, in a social relationship (Tatsis \& Zito, 2015). The use of the concept of power (power) is closely related to critical discourse analysis by Teun A. Van Dijk. This is because Van Dijk saw how social structure, domination, and power groups exist in society and how cognition and awareness form and influence certain texts (Eriyanto, 2011).

This method analyzes the use of language, especially by the authorities because they have the means and opportunity to improve the situation or abuse power (Haryatmoko, 2016). Constructing language; individuals try to give meaning to phenomena or engage in social activities, namely when language is used as a power strategy

\section{METHOD}

This study uses a qualitative approach. A qualitative approach is a research procedure that produces descriptive data in the form of written and oral words of the observed subject (Creswell, 2010). The qualitative approach is characterized by the existence of social constructions of reality and cultural meaning, where authenticity is the key to this approach. This approach focuses on words rather than quantity in collecting and analyzing data. With a qualitative approach, researchers are expected to link phenomena that occur in society in the form of text. So that the explanation in the study of a symptom of this social phenomenon will be intact. The data obtained is actual data with the interpretation of the meaning behind it.

This study uses content analysis as a data collection technique. The object of observation is a video and script of Donald Trump's speech about his official statement recognizing Jerusalem as the capital of Israel. Based on Van Dijk's text theory, the structure of the text must be analyzed by critical linguistics, which analyzes how discourse strategies are used to describe a particular person or event and how textual strategies are used to eliminate or marginalize a particular group, idea, or event. Text structure, in observing the structure of the text seen from several levels that each part supports each other. Van Dijk divides it into three levels: macro structure, superstructure, and microstructure.

The author adds several schemes in the schematic discourse element (superstructure) by Teun A. Van Dijk to dissect research objects, namely (1) Person Schemas, (2) Self Schemas, (3) Role Schemes (Role Schemas), and (4) Event Schemes (Schemas Event) 


\section{RESULTS AND DISCUSSION}

\section{Text Structure Analysis}

The author uses a news article entitled Full Video and Transcript: Trump's Speech Recognizing Jerusalem as the Capital of Israel which contains videos and complete transcripts of Donald Trump's presidential speech as an object to study the structure of the text. Based on Van Dijk's discourse theory, there are 3 text structures that can be analyzed, namely macro structure, superstructure, and microstructure. Quoted from Eriyanto (2001), the structure of discourse is an effective way to see the rhetoric and persuasion processes that are carried out when someone delivers a message. Certain words may be chosen to reinforce choices and attitudes, form political awareness, and so on.

\section{Macro Structure}

The thing identified in this structure is the global meaning of a text that can be observed from a topic or theme raised by a text (Eriyanto, 2001: 227). In other words, the thing analyzed is the theme presented as a general description of the news article, namely Donald Trump's official statement as President of the United States to recognize Jerusalem as the capital of Israel.

\section{Superstructure}

The framework of a text, such as the introduction, contents, conclusions, and conclusions. In the intended news article, the introductory section is filled with the main idea or general description of the events reported, namely:

President Trump on Wednesday officially recognized Jerusalem as the capital of Israel, reversing the decades of American foreign policy.

While the content section is a clause that explains details about the place and situation in which the speech was carried out, namely at the White House reception room with Vice President Mike Pence standing behind President Trump.

Mr. Trump made the formal announcement during a speech in the Diplomatic Reception Room of the White House, with Vice President Mike Pence standing behind him.

Then in the closing section, the news article directs the complete transcript of the speech. The following is a transcript of his remarks, as prepared by The New York Times.

The scheme is an element included in the superstructure, so the scheme in the text of Donald Trump's presidential address is mapped as follows:

\begin{tabular}{|l|l|}
\hline \multicolumn{1}{|c|}{ SCHEME } & \multicolumn{1}{|c|}{ EVIDENCE } \\
\hline Person Schemas & $\begin{array}{l}\text { "...That is why consistent with the } \\
\text { Jerusalem embassy act, I am also directing } \\
\text { the State Department to begin preparation }\end{array}$ \\
\hline
\end{tabular}




\begin{tabular}{|l|l|}
\hline $\begin{array}{l}\text { Demonstrate how Trump describes and } \\
\text { views other people (architects, engineers, } \\
\text { and planners) to carry out his direction. }\end{array}$ & $\begin{array}{l}\text { to move the American embassy from Tel } \\
\text { Aviv to Jerusalem. This will immediately } \\
\text { begin the process of hiring architects, } \\
\text { engineers and planners so that a new } \\
\text { embassy, when completed, will be a } \\
\text { magnificent tribute to peace." }\end{array}$ \\
\hline $\begin{array}{l}\text { Self Schemas } \\
\text { How Trump looks, understands, and } \\
\text { describes himself by using the word "I". }\end{array}$ & $\begin{array}{l}\text { time to officially recognize Jerusalem as the } \\
\text { capital of Israel." }\end{array}$ \\
\hline $\begin{array}{l}\text { Role Schemas } \\
\text { How Trump describes the roles and } \\
\text { positions he occupies in society using 2 }\end{array}$ \\
$\begin{array}{l}\text { terminology, namely "me" (personal) and } \\
\text { "The United States" (representing the United States remains deeply } \\
\text { committed to helping facilitate a peace } \\
\text { agreement that is acceptable to both sides. } \\
\text { Inited States as head of state). }\end{array}$ & $\begin{array}{l}\text { intend to do everything in my power to } \\
\text { help forge such an agreement." }\end{array}$ \\
\hline $\begin{array}{l}\text { Event Schemas } \\
\text { How Trump confronts events and how } \\
\text { they are displayed, expressed, and } \\
\text { interpreted as a positive step for Israeli } \\
\text { and Palestinian peace efforts. }\end{array}$ & $\begin{array}{l}\text { "...Today, I am delivering. I've judged this } \\
\text { course of action to be in the best interests } \\
\text { of the United States of America and the } \\
\text { pursuit of peace between Israel and the } \\
\text { Palestinians. This is a long overdue step to } \\
\text { advance the peace process. And to work } \\
\text { towards a lasting agreement." }\end{array}$ \\
\hline
\end{tabular}

\section{Micro Structure}

The local meaning of a text can be observed from the choice of words, sentences and styles used by a text. The micro structure consists of semantic, syntactic, stylistic, and rhetorical. If described in more detail, the following is a description of one by one element of Van Dijk's discourse belonging to the 3 discourse structures.

\section{Semantics}

This element of discourse shows the meaning that you want to emphasize in a text by adding detail, background, and purpose. Background is a news section that can influence the semantic (meaning) that you want to display. Background can be a justification for the ideas put forward in a text. In other words, the background can uncover what intents Trump wants to convey in his speech. The following is the background of events that are the basis of the meaning of the text.

"...We cannot solve our problems by making the same failed assumptions and repeating the same failed strategies of the past. All challenges demand new approaches."

This sentence is interpreted as Trump's attempt to show that his decision as head of state of the United States to recognize Jerusalem as the capital of Israel is the beginning of a new approach to address the Israeli-Palestinian conflict, where previous policies were considered assumptions and strategies failed to solve problems. Meanwhile, detail as an element of discourse relates to information control that is intentionally arranged in number (many or few) to create a particular image to the public. 
"...Jerusalem is not just the heart of three great religions, but it is now also the heart of one of the most successful democracies in the world. Over the past seven decades, the Israeli people have by the a country where Jews, Muslims and Christians and people of all faiths are free to live and worship according to their conscience and according to their beliefs."

"...Jerusalem is today and must remain a place where Jews pray at the Western Wall, where Christians walk the stations of the cross, and where Muslims worship at Al Aqsa Mosque."

Trump said that for Jerusalem Jerusalem is the heart of 3 great beliefs; Jews, Muslims and Christians. That these 3 beliefs have lived and settled in Israeli society. He also mentioned that Yerssalem is one of the biggest supporters of democracy. The image that Trump wants to show is concern for the democratic rights and security of places of worship that are shaded by these beliefs.

"While previous presidents have made this a major campaign promise, they failed to deliver."

The sentence above is a positive image that is trying to be shown as the fulfillment of the US president's promise that failed to be realized in the previous government.

\section{Syntax}

This element of discourse shows the form or composition of sentences that are deliberately chosen as manifestations of power and political manipulation to show a positive self-image. This can be reflected in the form of sentences, coherence (conjugations), and pronouns.

"...We want an agreement that is a great deal for the Israelis and a great deal for the Palestinians."

"...There will, of course, be disagreement and dissent regarding this announcement. But we are confident that ultimately, as we work through these disagreements, we will arrive at a peace and a place far greater in understanding and cooperation."

In the first sentence, Trump uses the word "and" as a conjugation to emphasize that this action not only provides benefits or takes sides with Israel, but also Palaestina. In the second sentence, the conjunction used is "but" to show that although there will be pros and cons regarding the decision, the action is taken as an effort to achieve peace and cooperation. The "but" conjugation is used as an emphasis on a contradictory situation but justifies the argument.

\section{Stylistic}

This element of discourse is called the lexicon, indicating how Trump chooses certain words for the various possible words available. Thus, the choice of words 
used is not by chance, but shows their attitude, ideology, and meaning toward reality.

"...Lifting our sights to what is possible, not pulling us back and down to the old fights that have become so totally predictable."

"...But the incredible future awaiting this region is held at bay by bloodshed, ignorance and terror."

In the first sentence, instead of using the word conflict, Trump chooses the word fight which means a fight or fight to emphasize or underline the importance of the events raised. Whereas in the second sentence, the future situation of the Middle East is described as incredible or "extraordinary" to illustrate a good future without the terror and bloodshed that is happening now. Trump chose the word to exaggerate a "better" future.

\section{Rhetorical}

In the rhetorical part, the discourse elements observed are graphics, metaphors, and expressions. Graphic is part of checking what is emphasized or highlighted (which means it is considered important) by someone from the text. While the metaphor is an allegory, proverb, proverb, or special expression as a spice in the text.

"Peace is never beyond the grasp of those willing to reach it."

The above proverb as well as the sentence of persuasion that nothing is impossible - including achieving peace in the Israeli-Palestinian conflict - if there is a desire to achieve it.

“...let us rededicate ourselves to a path of mutual understanding and respect. Let us rethink old assumptions and open our hearts and minds to possible and possibilities."

"...It is time for the many who desire peace to expel the extremists from their midsts. It is time for all civilized nations and people to respond to disagreement with reasoned debate, not violence."

The sentence using the word "let us" means an invitation (persuasion) and the use of the word "it is time" emphasizes the urgency of Trump's invitation.

\section{Donald Trump's Practices of Power and Domination as Nation Building}

To see the practice of Trump's domination and power, the author relates it to the practice of power according to Van Dijk, where power is defined as ownership owned by a group (or its members) to control groups (or members) of other groups. Power is associated with ownership of status, money, and knowledge. In addition to being direct (physical), 
control can also be a persuasive invitation by including trust, mental conditions, attitudes, and knowledge (Eriyanto, 2001: 272). In this case, Trump as president of the superpower, namely the United States of America supports his argument in recognizing Jerusalem as the capital of Israel - despite reaping contradictions and contradicting the foreign policy of the United States so far - with sentences of persuasion in the name of regional peace. Meanwhile Van Dijk specifically mentioned that discourse analysis gives great attention to what is called domination. His role as President who can influence Congress to approve a very controversial idea is evidenced in the text as follows:

"...This act passed congress by an overwhelming bipartisan majority. And was reaffirmed by unanimous vote of the Senate only six months ago."

This sentence confirms that the decision to recognize Jerusalem as the capital of Israel has been discussed for a long time and approved by a majority of members of Congress, and obtaining absolute votes from the Senate.

\section{CONCLUSION}

Research with critical discourse analysis by Teun A. Van Dijk is generally used to determine the meaning of a text based on its text structure, namely macro structure, superstructure, and microstructure. The object of the research was the text in the form of a complete transcript of Donald Trump's presidential speech obtained from a news article about his recognition of Jerusalem as the capital of Israel. After analyzing the data, the conclusions taken to answer the formulation of the problem raised are as follows:

The text discourse about Donald Trump's speech seen from the technical steps of analyzing data based on Critical Discourse Analysis by Teun A. Van Dijk, among others:

- In terms of thematic (macro structure), discourse elements such as topics and subtopics are clearly explained.

- This text explains the schematic aspect (superstructure) with implicit and must dissect the text to look for words that show the scheme.

- In explaining the microstructure which consists of semantic, syntactic, stylistic, and rhetorical, some elements of discourse such as background, detail, intent, coherence, sentence form, lexicon, and expression are found in the text. Whereas there is no element of graphic discourse because this text is a direct transcript of Donald Trump's presidential speech so that it does not have italicized, bold, underlined or specific deliberate tables and graphs.

The practice of power and domination of Donald Trump as president of the superpower is reflected in several parts of the sentence in the text. These sentences are arranged in persuasive language in the name of efforts to achieve peace for the Israeli and Palestinian conflict. 


\section{REFERENCES}

Creswell, John W. (2010). Research Design. Pendekatan Kualitatif, Kuantitatif, dan Mixed. Third Ed. Yogyakarta: Pustaka Pelajar.

Denzin and Lincoln. 1994. Hand book of Qualitative Research. London: Sage Publication.

Eriyanto. (2001). ANALISIS WACANA: Pengantar Analisis Teks Media. LkiS Yogyakarta.

Full Video and Transcript: Trump's Speech Recognizing Jerusalem as the Capital of Israel. (2017). The New York Times. Retrieved on March 252018 from https://www.nytimes.com/2017/12/06/world/middleeast/trump-israel-speechtranscript.html

Gustari, I. (2017). Mencermati Donald Trump dari Berbagai Sisi. Riau Pos, Retrieved on May 182018 from http://riaupos.co/4984-opini-mencermati-donald-trump--dariberbagai-sisi.html\#.WwJAUMQU_IU

Haryatmoko. (2016). Critical Discourse Analysis (Analisis Wacana Kritis) Landasan Teori, Metodologi, dan Penerapan.

Kotimah. (2016). Pengaruh Terpilihnya Pemimpin Baru Negara Adi Kuasa bagi Perekonomian Indonesia. Kompasiana, Retrieved on May 252018 from https://www.kompasiana.com/kotim/pengaruh-terpilihnya-pemimpin-barunegara-adi-kuasa-bagi-perekonomian-indonesia_58490c49329373a90f42915b

Landler, M. (2017). Trump Recognizes Jerusalem as Israel's Capital and Orders U.S. Embassy to Move. The New York Times. Retrieved on May 162018 from https://www.nytimes.com/2017/12/06/world/middleeast/trump-jerusalemisrael-capital.html

Tatsis, N., Zito, G. (2015). On Max Weber's Definition of Power. University of Sydney. SAGE Publication.

Van, D. (1993). Principles of critical discourse analysis. Discourse and Society, SAGE (London, Newbury Park and New Delhi), Vol. 4(2): 249-283. 
THE DOMINANCE OF POWER OVER THE FIGURE OF DONALD TRUMP IN THE OFFICIAL PRESIDENTIAL SPEECH OF THE UNITED STATES OF AMERICA

Ayu Tiara Maretha 